\title{
Simulation of FOMC Meeting: Learning About Monetary Policy by Doing*
}

\author{
Hiranya K Nath ${ }^{\dagger}$
}

First draft: October 2004

Revised: January 2005

\begin{abstract}
This paper explains a classroom simulation of the FOMC meeting designed for an upper-level monetary economics class. This is a role-playing simulation in which students are assigned various roles as an individual or as a group which directly or indirectly participates in the FOMC meeting and in the conduct of monetary policy. As the semester progresses with lectures that explain central banking, monetary policy making and effects of money in the economy, these groups research different aspects of the U.S. economy and prepare the green book, the blue book and the beige book. By the end of the semester, the FOMC meets and deliberates over the information gathered by various groups, determines the course of the overall economy and takes a decision on the monetary policy action.
\end{abstract}

Key words: Simulation of the FOMC Meeting; Monetary Policy; Green Book, Blue Book; Beige Book

JEL Codes: A2; E5

\footnotetext{
* I am thankful to the students at SHSU who took my Monetary Economics class in the fall 2004 and participated in the simulation. I am also grateful to the participants at the Teaching Economics Western Conference at California State University Fullerton, October 21-23, 2004 for their comments on an earlier version of the paper and for their enthusiasm.

${ }^{\dagger}$ Department of Economics and International Business, Sam Houston State University, Huntsville, TX

77341-2118; Phone: 936-294-4760; Fax: 936-294-3488; E-mail: eco_hkn@shsu.edu
} 


\section{INTRODUCTION}

Most macroeconomics textbooks - both at principles and intermediate level introduce monetary policy as a device to change money supply in the economy. ${ }^{1}$ They also explain how the stock of money determines the price level and change in it determines inflation in the long-run, and how the monetary may help stabilize an economy that is derailed from its long-run equilibrium path in the short-run. It leaves little room for explaining the practical details of monetary policy making and therefore, seems to impart only a partial understanding of how monetary policy actions help thr monetary authority achieve its short-run and long-run macroeconomic goals. Students are often puzzled by the report of the Fed's decision to change interest rate as a means to increase the money supply and oblivious of how it translates into open market operations about which they learn from the textbooks.

An advanced treatment of the topic in the money and banking textbooks sometimes leaves students equally puzzled because the myriad of topics - often with overwhelming details - covered in such books, even if selected chapters are covered in a one-semester class, make it hard for most students to connect the 'dots' that bring out the importance of money and monetary policy. Moreover, they project monetary policy making as an impersonal pursuit completely devoid of psychological, sociological and political aspects of economic decision making. These make it difficult for the teachers to motivate the students for most of whom it becomes a dry and uninteresting topic. A simulation of the Federal Open Market Committee (FOMC) meeting that requires an understanding of how money affects the economy and the knowledge of the conduct of 
monetary policy, gives students an opportunity to learn about the Fed's monetary policy by doing. ${ }^{2}$

Classroom simulations are widely used as a teaching technique across disciplines.

${ }^{3}$ In economics, models with strategic interactions that use game theory are often taught effectively by the use of in-class simulation games (for example, Meister (1999)). ${ }^{4}$ Simulations have also been effectively used to help students imbibe a better understanding of economic policy making. For example, Bartlett and Amsler (1979) discuss the use of a synergistic simulation of the Federal Open Market Committee. ${ }^{5}$ Rodgers (1996) and Lowry (1999) use simulations for classroom exposition of the Dutch disease and the General Agreements on Tariffs and Trade (GATT) respectively. In fact, following suggestions made by Morris (1979), Lowry (1999) develops a simulationbased course on GATT.

This paper presents a classroom simulation of the FOMC meeting designed for an upper-level monetary economics or money and banking class. This simulation is different from the one in Barlett and Amsler (1979) in that the simulation takes place as an evolving process that signifies the culmination of a semester long lectures in the class on money and monetary policy and students' efforts to gather facts and apply their acquired knowledge and insights from the lectures to determine appropriate policy actions. This is a role-playing simulation that emphasizes active participation of all students in the class and similar in spirit to Lowry (1999). The paper is organized as follows. Section 2 discusses the context and rationale for the simulation. The organization and various stages of the simulation are described in Section 3. In Section 4, we discuss the 
effectiveness of the simulation. A few concluding remarks are included in the next section.

\section{CONTEXT AND RATIONALE FOR THE FOMC SIMULATION}

This simulation of the FOMC meeting is intended for an upper-level monetary economics class (or a money and banking class) with the prerequisite of at least a macro principles class. Students with basic level of knowledge about how the overall economy works are expected to develop an understanding of (i) how money affects the economy in the short-run as well as in the long-run, and (ii) how the central bank along with the banking system and the nonbank public can affect the money supply in the economy. The emphasis is on the role of monetary policy in stabilizing an economy experiencing shortrun fluctuations without losing sight of the fact that in the long-run the policy aims at achieving dual objectives of economic growth and price stability. Since the monetary policy decision at the FOMC meeting represents the culmination of a process that is commensurate with these two broad objectives of the class, simulation of this meeting is a natural choice as a teaching technique.

Why is simulation better than simple textbook exposition? Economic theories are abstraction of reality. Although they provide important insights into economic behavior and may provide guidance for good economic decision making, economic decision making in general, and policy decision in particular, is a function of a constellation of factors which may be summarized as below: ${ }^{6}$

$D=F$ (Economic Theory, Personal Beliefs and Convictions of the Decision Makers, Sociological and Political Factors, Unintentional Ignorance of the Decision Makers) 
Economic theory provides a baseline understanding of the way the world works objective analysis of human behavior, and economic decision making combines this understanding with subjective elements which are often defined by the environment. A simulation of the FOMC meeting gives students an opportunity to combine their understanding derived from economic theories with other factors which go into the decision making process. The students are expected to appreciate the practical relevance of the insights they acquire from economic theory and the importance of policy decisions for our every day life. In the process, they also learn how to establish links between various topics covered over the semester which - because of the length of their details sometimes look disjoint pieces. In other words, the FOMC simulation has been conceived as a 'course integrator' (a la Morris (1979)). ${ }^{7}$

\section{ORGANIZATION AND STAGES OF THE SIMULATION}

\section{Organizational framework}

The Federal Open Market Committee (FOMC) is the most important policy making body of the Federal Reserve System. It consists of seven members of the board of governors, the president of the Federal Reserve Bank of New York and four presidents

from other eleven Federal Reserve Banks who serve at the FOMC on a rotating basis. Although these twelve members vote on policy decisions others in the Federal Reserve System participate and contribute to the FOMC meeting. The presidents - even if they do not vote - take part in the discussions. The research staff at the Board of Governors of the Federal Reserve System prepares the green book that contains a detailed forecast of the US economy and the rest of the world, and the blue book that presents the staff's view on 
the behavior of reserves, interest rates, and lays out alternative policy options. These two key documents are circulated before the meeting. The green book serves as the basis for the discussion at the FOMC meeting and the blue book provides the policy guidelines.

The research staff at each Federal Reserve Bank puts together the beige book based on the responses they receive from their 'contacts' in different sectors in their respective districts. The beige book is released about two weeks prior to the FOMC meeting. The staff also gathers the materials for the president's presentation at the FOMC meeting which includes an overview of his or her district and the bank's assessment of the national outlook. Often the senior bank officials attend the FOMC meeting. This operational framework provides the guidelines for organizing the simulation of the FOMC meeting.

Since one of the this simulation is conceived as a course integrator that helps understand the interlinkages between the topics covered in the class, the choice and organization of those topics are of crucial importance. ${ }^{8}$ Although students are expected to acquire knowledge about actual functioning of the system and to develop insights within the analytical framework of the monetary theories it is important to leave some room for their judgments in policy making. The FOMC meeting is an exercise that admittedly uses subjective judgments that are based on objective scientific findings. ${ }^{9}$ Likewise, in this simulation the students base their judgments on their understanding about the economy they acquire from the lectures in the class and the information they gather about the current state of the economy. 


\section{Scope and organization of the lectures}

In the beginning of the semester, I give a broad overview of the financial system and explain how money fits into the system. The discussion includes definition, functions and measurement of money. We immediately move on to the Federal Reserve System, the U.S. central bank, discussing its structure, organization and functions with particular emphasis on the FOMC. We discuss the monetary policy tools, mainly focusing on open market operations, discount loan and reserve requirements. The money supply process and the role of the Fed and other players - banks and nonbank public (as depositors and borrowers) in it, are discussed using the balance sheets of the Federal Reserve System and the banking system. A further formalization in the form of a money supply model contributes to the understanding of the students by emphasizing the role of behavioral aspects of the players in the money supply process.

The link between open market operations and federal funds rate is explained by a model of the market for reserves. It is explained to the students why the recent practice of setting primary discount rate 100 basis points above the target rate has been aimed at reducing the amount of borrowed reserves thus giving Fed more control over the monetary base.

Next we move on to the theories that explain how money affects the economy. First, we discuss how money supply affects price and interest rate in the long-run with detailed discussion of the quantity theory and the Fisher effect. We use an Aggregate Demand - Aggregate Supply (AD-AS) Model to understand the role money supply and monetary policy play in influencing the short-run behavior of the economy. The IS-LM framework is used to explain the $\mathrm{AD}$ curve. On the supply side in the short-run, two 
different points of view are discussed. The new classical position invokes imperfect information to explain sluggish adjustments of prices and wages in the short- run. The new Keynesian position, on the other hand, ascribes sluggish adjustments in prices to long-term contracts and imperfect competition among sellers in the goods market.

\section{Stages of the simulation}

Although the simulation of the FOMC meeting takes place just before the semester ends the preparation starts much earlier. The simulation is executed in three stages.

\section{Stage 1:}

In the beginning - some time around the structure and organization of the Fed is discussed in the class, the students are divided into several indivual/group participants as shown in Table 1. This simulation requires a minimum of 23 students. Depending on the total number of students in the class, more than one student can be assigned to different groups. After the roles and responsibilities of various individuals/groups are explained the students are asked to choose a group. Each student is asked to provide with a brief biographical note and, if possible, a picture for the FOMC Simulation Webpage. The webpage is not only a source of information but it can also be a forum for discussion and correspondence among the students. Furthermore, each group is asked to visit the relevant website and familiarize itself with the activities of the group. For example, the students representing the Federal Reserve Bank of Boston will look up at the Boston Federal Reserve Bank website. At this stage the students are allocated about two weeks. 


\section{Stage 2:}

Each group meets with the instructor separately and starts working on their roles in the FOMC meeting. The governors including the chairman closely monitor the activities of the Fed governors: read their most recent speeches, read minutes and transcripts of the of the most recent FOMC meeting. ${ }^{10}$ They also monitor the current macroeconomic performances. Each governor prepares his or her outlook of the national economy. The Research and Statistics Division at the Federal Reserve Board of Governors prepares the green book that presents its forecasts for the U.S. and foreign economies for next two years on growth, employment, price level and inflation, and so on and so forth. The Monetary Affairs Division prepares the blue book presenting its view on the behavior of reserves, interest rates, and giving three different scenarios for monetary policy actions. The Manager of the System Open Market Operations writes a report on foreign currency reserves and domestic open market operations since the last FOMC meeting. The groups representing different Federal Reserve Banks collect information about the economic health of their respective Federal Reserve districts and prepare the beige book. They also include the view of the respective districts on the national economy. Each group meets with the instructor at least once at this stage and they extensively discuss their thoughts and ideas, and clarify doubts, if there are any.

\section{Stage 3:}

This is the final stage. The FOMC voting members meet with the instructor and discuss their thoughts on the economy and clarify conceptual problems, if any. They also read the green book and the blue book which are made available to them before the 
meeting. Finally, the FOMC meeting is held. Every student is attired in formal clothes so that he or she looks professional.

The meeting is held in a large conference room. The seven governors, the 12 Reserve Bank presidents, the secretary of the FOMC, the Board's director of the Research and Statistics Division and his deputy, and the director of the Monetary Affairs Division, sit around a conference table. The directors of research at the Reserve banks and other senior board and Reserve Bank officials sit around the sides of the room. Upon the chairman's invitation, the vice chairman (who is the president of the Federal Reserve Bank of New York) moves the minutes of the previous meeting. The manager of system open market operations presents a report on foreign currency and domestic open market operations and other related issues. The governors and the bank presidents ask questions and discuss the report before they vote to ratify it.

The director of the Research and Statistics division then presents the green book that gives the staff's national economic forecast. The governors and the bank presidents ask questions to the director. Then each bank president presents an overview of economic conditions in his or her district and the bank's assessment of the national outlook, and each governor, except for the chairman, gives a view of the national outlook. There is a coffee break.

After the break, the director of the Board's Monetary Affairs Division presents the blue book that outlines different scenarios for monetary policy actions. The governors and the bank presidents ask him questions on his presentation. Then, the chairman of the Fed presents his views on the state of the economy and makes a recommendation for monetary policy action. The FOMC members and nonvoting bank presidents express 
their views on monetary policy, and the chairman summarizes the discussion and proposes specific wording for the directive on the federal funds rate target transmitted to the open market trading desk. The secretary of the FOMC formally reads the proposed statement, and calls the names of the voting members to which they respond by saying ‘yes' or 'no'. Finally, a public announcement is made about the outcome of the meeting: whether the target federal funds rate and discount rate have been changed, and an assessment of the "balance of risks" in the future, whether toward higher inflation or toward a weaker economy.

\section{Evaluation of the students}

This simulation of FOMC meeting accounts for 20 percent of a student's overall grade. Therefore, there is an incentive for the students to actively participate in the exercise. Each group is evaluated on the basis of the quality of its work. In order to eliminate the 'free rider' problem group members are asked to evaluate each other for their participation, and their individual scores are then determined by combining the group evaluation and individual participation evaluation. ${ }^{11}$

\section{EFFECTIVENESS OF THE SIMULATION}

In order to evaluate the effectiveness of the simulation three different procedures are followed. First, the reports prepared by various groups are collected and carefully examined to see if they are able (i) to collect the most relevant information and (ii) to articulate their thoughts to achieve the intended goals: an understanding of how different parts of the economy work. The entire meeting is videotaped and later on the tape is 
analyzed to see if the participants are coherent and consistent in their arguments. Of particular importance is the articulation of their impromptu questions and responses.

Second, the monetary policy decision and the statement the FOMC simulation meeting issued at the end are compared to those of the actual meeting held after the simulation. ${ }^{12}$ Nowadays speculation about the Fed's monetary policy action abounds much before the FOMC meeting and in most cases experts in economics and businesses can correctly predict the action. Although enterprising students may take hint from those, the fact that they have to closely follow those discussions in media also contributes to the learning process.

After the meeting is over, the students are asked to fill out a survey that includes questions on what they think about the simulation. Appendix 2 includes a sample questionnaire. In my own experiment with this simulation in fall 2004, the results of this survey are compiled and summarized in Figure A.1 through A.3. Majority of the students (about $85 \%$ ) seemed to like the simulation. Almost all of them (98\% of a class of 56) think that they have now a better understanding of the link between the interest rate, open market operation and the money supply process. About a third of the students think that the simulation was educational while about 27 percent (there may be overlaps) thinks that it is a better way of learning.

\section{CONCLUDING REMARKS}

This paper explains a classroom simulation of the FOMC meeting designed for an upper-level monetary economics class. This is a role-playing simulation in which students are assigned various roles as an individual or as a group which directly or 
indirectly participates in the FOMC meeting and in the conduct of monetary policy. As the semester progresses with lectures that explain central banking, monetary policy making and effects of money in the economy, these groups research different aspects of the U.S. economy and prepare the green book, the blue book and the beige book. By the end of the semester, the FOMC meets and deliberates over the information gathered by various groups, determines the course of the overall economy and takes a decision on the monetary policy action.

The groups are evaluated on the basis of the quality of their work and participation in group effort. The effectiveness of the exercise is evaluated on the basis of (i) the students' understanding as reflected in their written report and verbal deliberations; (ii) a comparison of their policy decision and the policy statement with those of the actual FOMC meeting held immediately after the simulation; and (iii) the results of a survey conducted after the simulation.

As indicated by some of the students in their comments, in stage 1 it may not be clear what is expected from them. Since there is no rehearsal round, some students feel pressurized in preparing for the meeting. Playing a video tape of the previous simulation may be useful. It may also help the instructor explain the expectations on his/her part. Some students feel that those who get to speak in the meeting have advantage over the others who did not, in that they can better see the coherence among the topics discussed in the class. For a class of 24/25 students, everyone gets a chance to speak. For larger class size there could be more than one round of simulation as suggested in Bartlett and Amsler (1979). 


\section{NOTES}

${ }^{1}$ For example, Mankiw (2004) has one chapter on the central bank and money supply, one chapter on money growth and inflation and one chapter on how monetary policy, among other things, affects aggregate demand.

${ }^{2}$ In a recent paper, Lengwiler (2004) describes a computer game that shows students various aspects of monetary policy making using a simulated macro model.

${ }^{3}$ The dictionary meaning of simulation is 'the act of simulating; pretense, feigning, or false resemblance as through imitation'

${ }^{4}$ As Barlett and Amsler (1979) argue, economists often use simulations: they build models and simulate results but such simulations do not 'incorporate psychological, sociological, and political facets of the market framework into their models'.

${ }^{5}$ The Federal Reserve Bank of New York has a FOMC Simulation Game on its website, intended for high school students in 9-12 grades.

${ }^{6}$ See Maisel (1973)

${ }^{7}$ Commenting on why studies on the effectiveness of simulation find no positive results, Morris (1979) writes, 'the simulation often bears only a superficial relationship to the overall structure of the course..' and emphasizes better integration of the simulation exercise in the overall structure of the course.

${ }^{8}$ Most of the materials covered in the class are distributed as lectures. Alternatively, chapters from a money and banking textbook (e.g. Mishkin 2004 or Hubbard 2005) can be used.

${ }^{9}$ Commenting on the role of the Board's research staff in preparing forecast of the US and foreign economies in the Green book, Edison and Marquez (1998) writes 'This forecast is referred to as 'judgmental' projection because it does not rest solely on projections from any large scale econometric model. The Federal Reserve staff's models play a role, however, by (1) providing a baseline from which staff develops their judgmental Green book forecasts; and in (2) constructing alternative scenarios.' (pp.413-4)

${ }^{10}$ The most recent full transcript available on the Federal Reserve Board of Governor's website is for December 1998 FOMC meeting

${ }^{11}$ Of course, there is possibility of collusion among the group members.

${ }^{12}$ The statement issued at the end of the FOMC simulation in my class on December 1, 2004 is included in Appendix 1. It is compared to the actual statement issued on December 14, 2004 available on the Fed's website

(http://www.federalreserve.gov/boarddocs/press/monetary/2004/20041214/) 
Table 1: Group Assignments and Roles

\begin{tabular}{|c|c|c|}
\hline Group & No. of Students & Role \\
\hline Board of Governors & 7 & $\begin{array}{l}\text { Voting members of the } \\
\text { FOMC; the Chairman } \\
\text { conducts the FOMC } \\
\text { meeting }\end{array}$ \\
\hline $\begin{array}{l}12 \text { Groups representing } 12 \\
\text { Federal Reserve Banks }\end{array}$ & $\begin{array}{l}\text { Each group has at least } 1 \\
\text { member }\end{array}$ & $\begin{array}{l}\text { The president of the Federal } \\
\text { Reserve Bank of New York } \\
\text { will be a voting member of } \\
\text { the FOMC. He or she will } \\
\text { also act as the vice } \\
\text { chairman in the meeting. } \\
\text { Four other Bank presidents } \\
\text { will vote at the FOMC } \\
\text { meeting. Each group will } \\
\text { prepare reports on the } \\
\text { economic conditions in } \\
\text { their respective federal } \\
\text { reserve districts and } \\
\text { together will prepare the } \\
\text { beige book }\end{array}$ \\
\hline $\begin{array}{l}\text { Research and Statistics } \\
\text { Division }\end{array}$ & At least 1 member & $\begin{array}{l}\text { Prepares the green book } \\
\text { that includes forecasts of } \\
\text { the economy in the coming } \\
\text { months and years }\end{array}$ \\
\hline Monetary Affairs Division & At least 1 member & $\begin{array}{l}\text { Prepares the blue book that } \\
\text { presents three different } \\
\text { monetary policy scenarios }\end{array}$ \\
\hline $\begin{array}{l}\text { System Open Market } \\
\text { Operation Group }\end{array}$ & At least 1 member & $\begin{array}{l}\text { Presents reports on the day- } \\
\text { to-day activities of the } \\
\text { trading desk at the Federal } \\
\text { Reserve Bank of New York }\end{array}$ \\
\hline Secretary of FOMC & 1 & $\begin{array}{l}\text { He/she is a member of the } \\
\text { board's staff and works } \\
\text { with the research and } \\
\text { statistics or monetary } \\
\text { affairs division. In the } \\
\text { meeting he takes down the } \\
\text { minute, take dictation from } \\
\text { the chair to prepare the } \\
\text { statement, read it to the } \\
\text { meeting participants and } \\
\text { record the votes. }\end{array}$ \\
\hline
\end{tabular}




\section{Federal Reserve Release}

\section{Press Release}

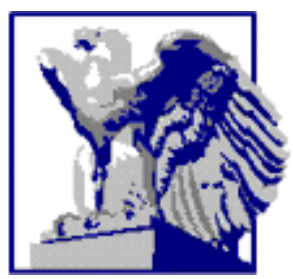

Release Date: December 1, 2004

For immediate release ${ }^{1}$

The Federal Open Market Committee decided today to raise its target for the federal funds rate by 25 basis points to 2.25 percent.

The Committee believes that, even after this action, the stance of monetary policy remains accommodative and is providing ongoing support to economic activity. With the upcoming holiday season the sales are expected to increase with output growing at a moderate pace. Labor market conditions have improved and these trends are expected to continue. Inflation and longer-term inflation expectations remain well contained.

The Committee perceives the upside and downside risks to the attainment of both sustainable growth and price stability for the next few quarters to be roughly equal. With underlying inflation expected to be relatively low, the Committee believes that policy accommodation can be removed at a pace that is likely to be measured. Nonetheless, the Committee will respond to changes in economic prospects as needed to fulfill its obligation to maintain price stability.

Voting for the FOMC monetary policy action were: James MacDonald, Chairman; Travis Tobaben, Vice Chairman; Greg Jones; Kevin Koronzok; Jason Lampley; Micah McCraw; Matt Puttoni; Nick Savarino; Brandy Wadenpful; Jake Philips; Atif Illyas; and Jeffry Williams.

In a related action, the Board of Governors unanimously approved a 25 basis point increase in the discount rate to 3.25 percent.

\footnotetext{
${ }^{1}$ This is the statement issued at the end of the simulation of the FOMC meeting held on December 1, 2004 at the Sam Houston State University and does not represent the Federal Reserve's policy decision
} 


\section{APPENDIX 2}

\section{Survey on FOMC Meeting Simulation}

Instruction: Take a few minutes to answer the following questions.

1. How did you like the FOMC meeting simulation?

a. liked it very much

b. liked somewhat

c. neither liked nor disliked

d. did not like it

e. hated it

2. Did you take the Principles of Macroeconomics before?

a. YES

b. NO

3. Did you take the Intermediate Macroeconomics before?
a. YES
b. NO

4. Did you take any other class (other than the Principles of Macroeconomics and the Intermediate Macroeconomics) that discusses the Fed's monetary policy and the money supply process?
a. YES
b. NO

If yes, name of the class

If your answer to any of the question 2, 3 and 4 is YES, answer Question 5. Otherwise, go to Question 6

5. Do you think that the simulation exercise has added value to your understanding about the conduct of monetary policy and the money supply process in the U.S.?
a. YES

b. NO

6. Do you now understand better the link between the Fed's interest rate changes, open market operations and the money supply in the economy?
a. YES
b. NO

7. Overall, the FOMC meeting simulation was (Circle one or more from the following)
a. educational
b. of practical relevance
c. a better way of learning
d. a fun way of learning
e. not useful for a better understanding

8. If we have to do this exercise once again, would you like to see some changes?
a. YES
b. NO

If your answer is YES, explain briefly:

Thanks!

Name (optional): 
Effectiveness of the FOMC Meeting Simulation: the Survey Results

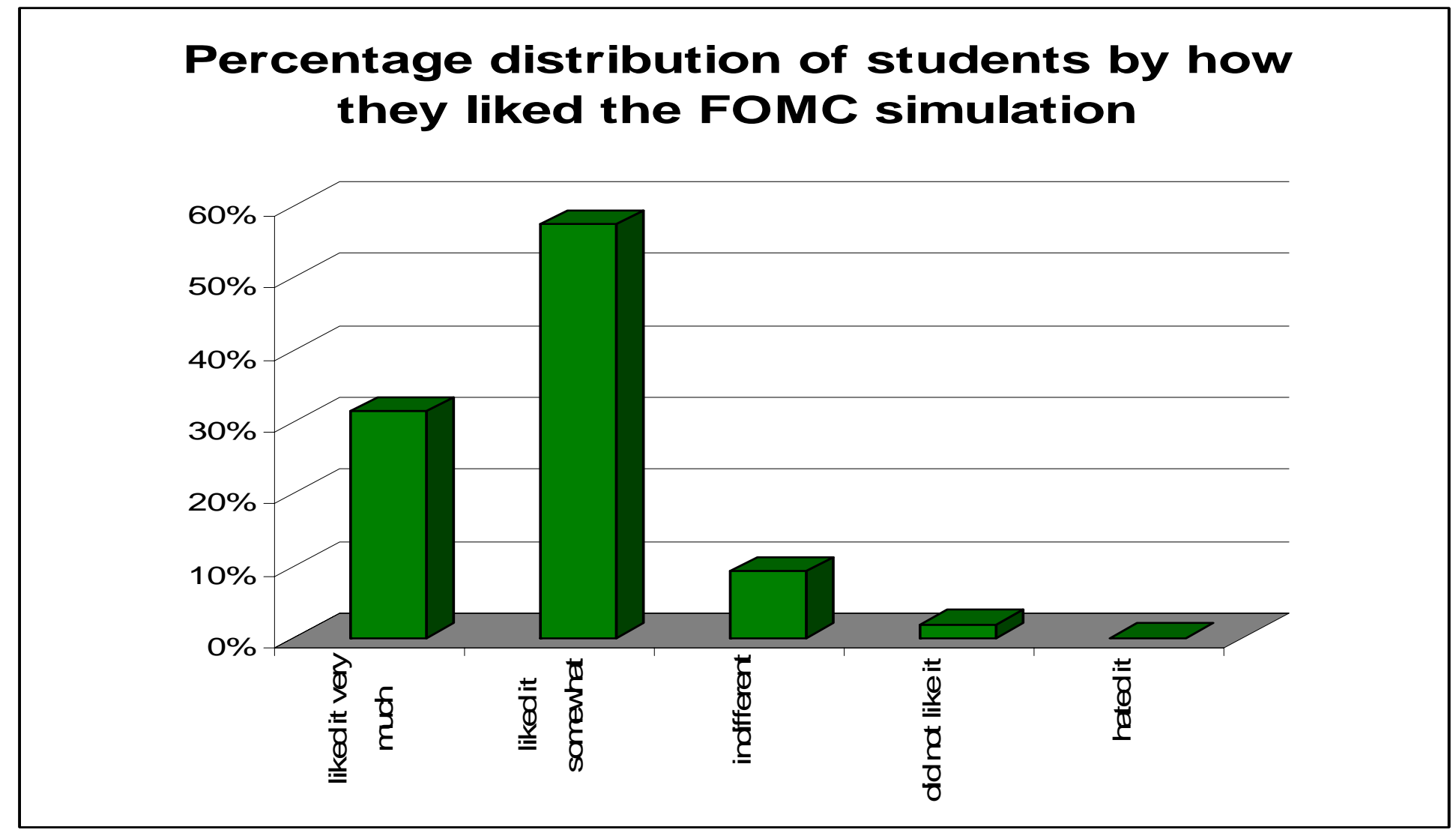

Figure A.1 
Do you now understand better the link between the Fed's interest rate changes, open market operations and the money supply process in the U.S.?

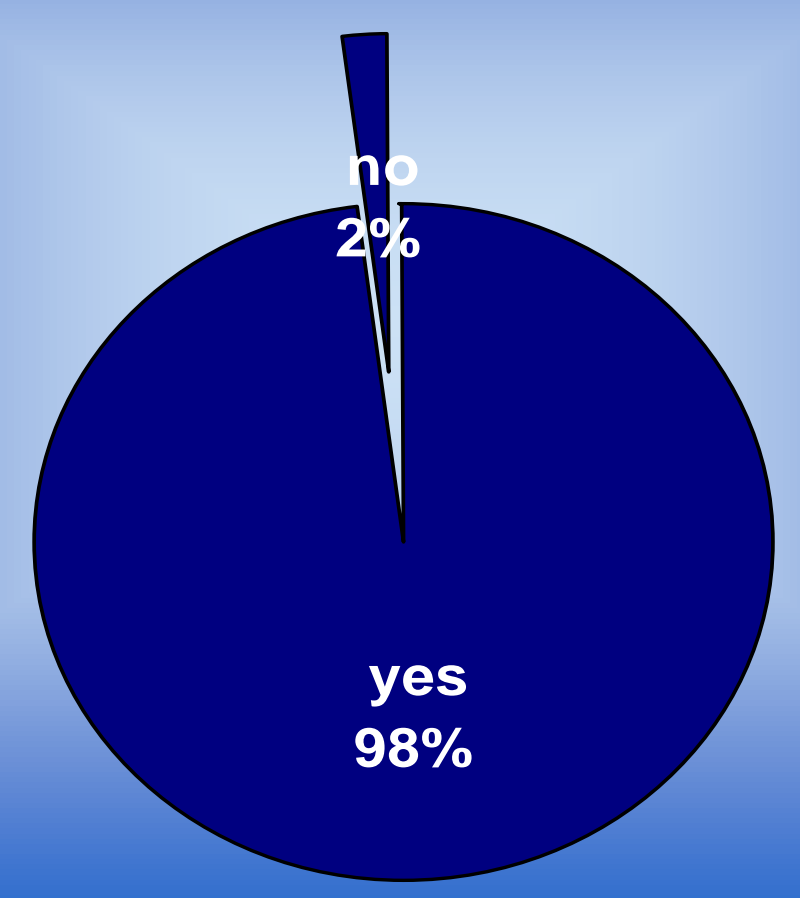

Figure A.2 


\section{Percentage distribution of students who think the FOMC simulation was}

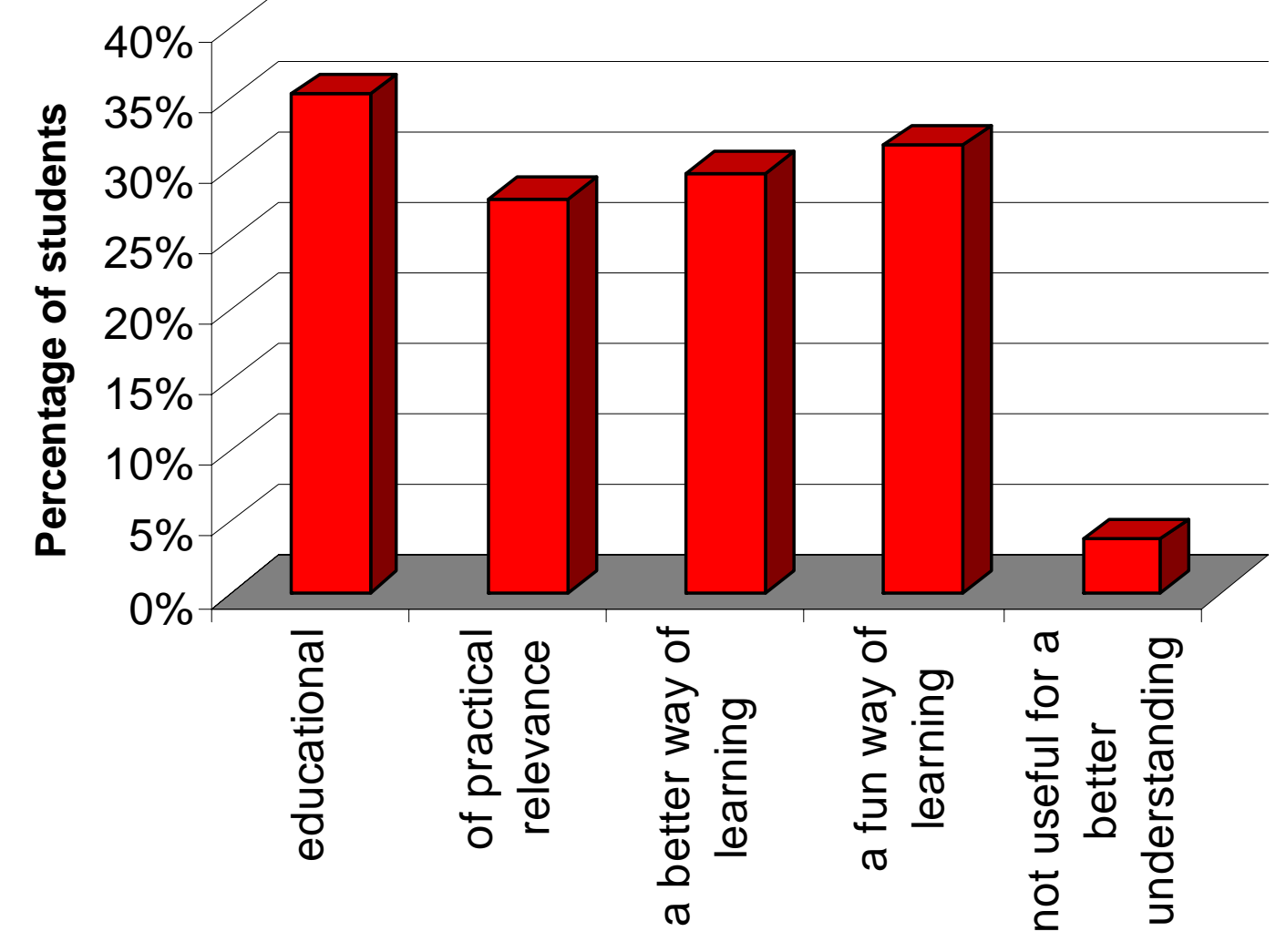

Figure A.3 


\section{REFERENCES}

Bartlett, Robin L. and Christine E. Amsler 1979. Simulations and Economics. In Simulation in Higher Education, ed. E. Thorson. Hicksville, NY: Exposition Press.

Board of Governors of the Federal Reserve System (various volumes) The Beige Book, Washington, D.C.

Board of Governors of the Federal Reserve System (various volumes) Transcripts and Minutes of the Federal Open Market Committee Board of Governors of the Federal Reserve System, Washington, D.C.

Edison, Hali J. and Jaime Marquez 1998. US monetary policy and econometric modeling: tales from the FOMC transcripts 1984 - 1991. Economic Modeling 15: 411 - 428.

Hubbard, R. Glenn 2005, Money, the Financial System, and the Economy, fifth edition, Boston: Pearson Addison Wesley.

Lengwiler, Yvan, 2004, A Monetary Policy Simulation Game. Journal of Economic Education 35 (Spring):175 - 183

Lindsey, D. 1997. How Monetary Policy is Made in Practice in the United States. Board of Governors of the Federal Reserve System, processed.

Lowry, Pamela E. 1999. Model GATT: A Role-Playing Simulation Course. Journal of Economic Education 30 (Spring): 119 -126.

Maisel, S.J. Managing the dollar. New York: Norton, Inc.

Makiw, Gregory N. 2004 Principles of Economics, third edition, Mason,OH: Thompson South-West.

Mishkin, Frederick 2004, The Economics of Money, Banking and Financial Markets, seventh edition, Boston: Pearson Addison Wesley.

Morris, Charles J. 1979 Simulation Evaluation Designs. In Simulation in Higher Education, ed. E. Thorson. Hicksville, NY: Exposition Press.

Rodgers, Y. 1996. A role-playing exercise for development and international economics courses. Journal of Economic Education 27 (Summer): 217-23. 